\title{
Acute effect of different stretching methods in classical dancer children
}

\author{
Efeito agudo de diferentes métodos de alongamento em crianças \\ dançarinas clássicas
}

\author{
Renata Nascimento', Mariana Desiree', Estêvão Rios Monteiro', Aline Ribeiro',3, Natália \\ Reis $^{2}$, Leandro Sant'Ana ${ }^{2}$, Jeferson Vianna ${ }^{2}$, Jefferson Novaes ${ }^{1,2}$, Amanda Brown 1,3,4 \\ 1. School of Physical Education and Sports, Federal University of Rio de Janeiro, Rio de Janeiro, Brazil. \\ 2. Faculty of Physical Education and Sports, Federal University of Juiz de Fora, Minas Gerais, Brazil. \\ 3. Faculty of Physical Education, UNIFAA - Center University of Valença, Brazil. \\ 4. Faculty of Medicine, Federal University of Rio de Janeiro, Rio de Janeiro, Brazil.
}

\begin{abstract}
Introduction: Dancers use to do stretching exercises to increase flexibility in the preparation and completion of training and activities. The purpose of the present study was to compare two methods of passive stretching of hip flexion in classical dancer children. Methods: Twenty-one female's children were recruited for the study, and each participant visited the laboratory on two occasions during three-days at least twenty-four hours between visits. A randomized within-subject design used to investigate the effects of three conditions: control (CG), static stretching (SS), and proprioceptive neuromuscular facilitation (PNF) applied to the posterior thigh, unilaterally, on passive hip flexion (HF) with 60-seconds. Results: There were no statistical differences for CG $(F=0.716 ; p=0.552)$, SS $(F=0.536 ; p=0.662)$ and PNF (F $=1.713 ; \mathrm{p}=0.191)$. Conclusion: The results found in the present study indicate that different stretching methods can promote increases in HF and PROM without difference between methods.
\end{abstract}

Key-words: Flexibility, Dancing, Youngster.

\section{RESUMO}

Introdução: Os dançarinos utilizam exercícios de alongamento na preparação e finalização de treinamentos e atividades para aumentar a flexibilidade. O objetivo do presente estudo foi comparar dois métodos de alongamento na amplitude de movimento passiva (AMP) da flexão do quadril no curso do tempo em crianças dançarinas clássicas. Métodos: Vinte e uma crianças do sexo feminino foram recrutadas para o estudo e cada participante visitou o laboratório em duas ocasiões durante três dias, com pelo menos 24 horas entre as visitas. As participantes foram distribuídas de forma randomizada para investigar os efeitos de três condições: controle (GC), alongamento estático (AE) e facilitação neuromuscular proprioceptiva (FNP) aplicada na posterior de coxa, unilateralmente, na flexão passiva do quadril por 60 segundos. Resultados: Não houve diferença estatística para $\mathrm{GC}(\mathrm{F}=0,716 ; \mathrm{p}=0,552), \mathrm{AE}(\mathrm{F}=$ $0,536 ; p=0,662)$ e FNP $(F=1,713 ; p=0,191)$. Conclusão: Os resultados encontrados no presente estudo indicam que diferentes métodos de alongamento podem promover aumentos na flexão do quadril e AMP sem diferença entre os métodos.

Palavras-chave: Flexibilidade, Dança, Crianças. 


\section{Introduction}

Classical ballet developed in the middle of the 16th century with the development of gestures and movement patterns that, over time, have been refined, requiring a higher physical performance that involves sensitivity, musicality, perception, neuromotor coordination, balance, muscle tone, laterality, time-space sensitivity and respiratory control [1]. Dancers have adopted stretching exercises to increase flexibility in the preparation and completion of training and activities $[2,3]$.

Among the different flexibility training methods used before sports activity, it can be mentioned static stretching (SS), and proprioceptive neuromuscular facilitation (PNF) $[4,3]$. This fact agrees with the American College of Sports Medicine [5], which recommends stretching exercises in a supervised training program to improve flexibility gains. Flexibility is considered part of the five necessary components of health-related fitness and adequate levels are required to ensure life, postural stability, balance, and sports performance [5-8].

Commonly, stretching exercises have been used as part of the warm-up routine for rehabilitation as athletic performance to increase passive range-of-motion (PROM) [9-14], increase in muscle performance [13,15,16] and local muscular endurance performance [17], but does not every time [18-21] increase cardiovascular response [22] and reduces delayed onset muscle soreness [23-25].

The classical ballet is based on natural human movements, and it requires actions that involving strength and flexibility, jumps, and supports [26]. Flexibility is considered necessary for the proper and smooth execution of the exercises. It seems as an essential component of physical training to obtain and maintain health, quality of life, and sports performance [7]. Several factors can influence the flexibility levels (i.e., sex, age, and training specificity), and few studies are found in the literature across these factors. Therefore, the purpose of the present study was to compare two methods of stretching on time course passive hip flexion range-of-motion in children classical dancer.

\section{Methods}

\section{Participants}

Twenty-one female children (Table I) recruited for the study. An a priori sample size calculation (effect size $=3.40 ; 1-\beta=0.95 ; \alpha=0.05$ ) using $G^{*}$ Power [27] found that 6 subjects would be adequate; however, in order to increase statistical power, 7 subjects in each group were recruited [28]. Anthropometric data included body mass (Techline BAL - 150 digital scale, São Paulo, Brazil) and height (stadiometer ES 2030 Sanny, São Paulo, Brazil). Participants were excluded from participation if they did not practice classical ballet, had any potential injury limitations or pre-existing medical conditions, answer positively in the Physical Activity Readiness Questionnaire (PAR-Q). Before the study, all participants were provided with a verbal explanation of the study and read and signed informed consent and PAR-Q [29]. All procedures were following the Declaration of Helsinki. 
Table I - Characteristics of participants.

$\begin{array}{ll}\text { Characteristics } & \\ \text { Age (years) } & 9.33 \pm 1.65 \\ \text { Height }(\mathrm{m}) & 1.41 \pm 0.11 \\ \text { Weight }(\mathrm{kg}) & 36.64 \pm 11.24 \\ \text { Body Mass Index } & 17.73 \pm 3.45 \\ \text { ICC baseline - CG } & 0.991 \\ \text { ICC baseline - SS } & 0.996 \\ \text { ICC baseline - PNF } & 0.999\end{array}$

ICC = intraclass correlation calculate; $\mathrm{CG}=$ control group; $\mathrm{SS}=$ static stretching; $\mathrm{PNF}=$ proprioceptive neuromuscular facilitation.

\section{Procedures}

A randomized (https://www.randomizer.org/) within-subject design used to investigate the effects of three conditions; control (CG), static stretching (SS), and proprioceptive neuromuscular facilitation (PNF) applied to the posterior thigh, unilaterally, on passive hip flexion (HF) with 60-seconds (Figure 1). Participants visited the laboratory on four occasions during seven-days with at least twenty-four hours between visits.

During the first visit, the participants underwent an anthropometric assessment. Each experimental session included two HF measures in a randomized order, which later averaged to determine a baseline. Following baseline measures, subjects were randomized to one of the three conditions (CG, SS, and PNF). Immediately following the intervention, passive HF measured again, PROM also assessed 10- and 20-minute following each intervention to evaluate the effects of stretching on PROM over an extended period. Only the dominant leg tested as referenced to the leg that they would kick a ball with [30].

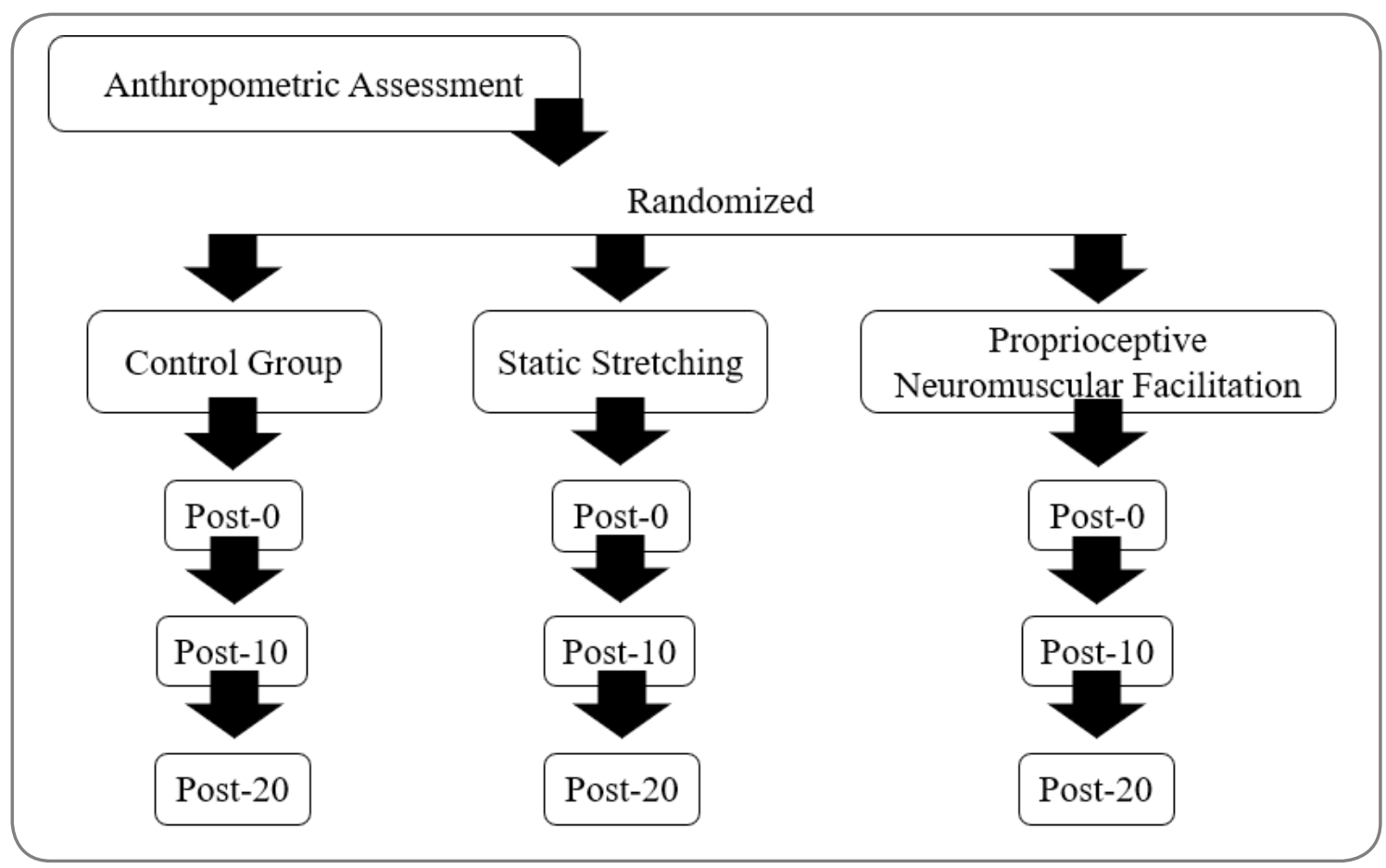

Figure 1 - Randomization process. 
Initially, participants arrived at the laboratory and cool down for 10-minute to minimize the thermal effects of muscle warm-up. Immediately after this period, the procedures involved in each experimental protocol performed. Throughout CG, no stretching technique performed, and only the HF and PROM was measured. Two kinds of stretching exercises (SS and PNF) applied for posterior thigh regions.

For each stretching exercise protocol, the movement taken to a position of slight discomfort [7] for a single set with a 60-second volume. Subjects instructed to maintain their usual respiratory pattern throughout all stretching exercises protocols. Stretching exercise interventions were performed at the same time of day to avoid possible diurnal variations. SS was performed passively with the dominant leg in the stretching position. For PNF procedures used a contract-relax technique [31]. Then, 1 set of 6 seconds of isometric contraction performed by the participants, and after that, a lengthened position held for 24 seconds.

This procedure was repeated two times for a total of 60-second. For each protocol, the movement conducted in a discomfort position [7]. In both techniques were performed stretching for the posterior thigh, which subjects lying in the supine position with arms and legs extended (Figure 2). Research raised the leg, with knee extended, performing HF until maximum position.

\section{Passive range-of-motion}

Passive HF (Figure 3) of the dominant leg measured with a manual goniometer (Trident, São Paulo, BRA) using the standardized procedures outlined by Norkin and White [32]. HF assessed in a supine position with the dominant knee flexed at 90 degrees, and the opposite knee extended. A blood pressure cuff placed under the lumbar spine and then inflated to $60 \mathrm{mmHg}$ [33]. This pressure monitored as the dominant leg passively lowered to the end of the PROM without associated changes in pelvic position or pressure in the blood pressure cuff [33]. The researcher then aligned the axis of the goniometer with the greater trochanter, and the arms of the goniometer with the lateral condyle of the femur and the mid-axillary line. When the trunk and thigh were parallel, $\mathrm{HF}$ and PROM defined as 0 degrees (positive PROM characterized by flexion of the hip). The arms relaxed beside the body throughout PROM testing. The same experimenter collected all PROM data and always blinded as to which intervention the participants had been subjected to.

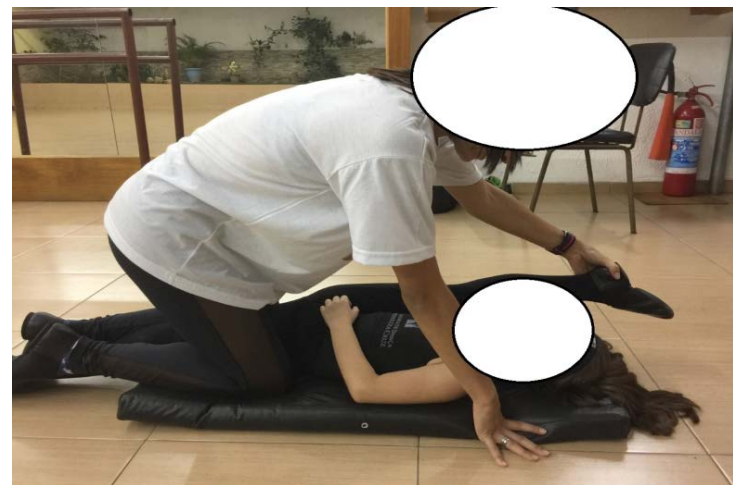

Figure 2 - Thigh posterior stretch demonstration. Figure 3 - Passive hip flexion demonstration. 


\section{Statistical analyse}

Data are presented as means \pm standard deviations. Normality and sphericity tested using a Shapiro-Wilk test homoscedasticity was confirmed by a Mauchaly' test. The baseline reliability was assessed by intraclass correlation calculate as ICC $=(\mathrm{MSb}-\mathrm{MSw}) /[\mathrm{MSb}+(\mathrm{K}-1) \mathrm{MSw})$, where $\mathrm{MSb}=$ mean-square between, $\mathrm{MSw}=$ mean-square within, and $\mathrm{K}=$ average group size. An ANOVA with repeated measures was used to test for an interaction. Additionally, effect size (ES) estimates calculated using standardized mean difference to determine the magnitude of the treatment effects. The ES represents the standardized within-group change for each measurement time point compared with baseline values (ES = [Mean Post - Mean Pre] / SD of the baseline). The magnitude of the ES interpreted using the scale proposed by Rhea [34] for recreationally trained subjects, were $<0.5,0.50-1.25,1.25-1.9$, and $>2.0$ represented trivial, small, moderate, and large effects, respectively. All analyses performed using SPSS version 21 (SPSS Inc., Chicago, IL, USA), and an alpha level of 0.05 accepted.

\section{Results}

For baseline's values check Table I. There were no statistical differences for $\mathrm{CG}(\mathrm{F}=0.716 ; \mathrm{p}=0.552)$, SS $(\mathrm{F}=0.536 ; \mathrm{p}=0.662)$ and PNF $(\mathrm{F}=1.713 ; \mathrm{p}=0.191)$ (Table II; Figure 4). Results regarding ES confirm these results indicating that the highest magnitude presented trivial classification (Table II).

Table II - ES for each post-exercise moment.

\section{Post-0 Post-10 Post-20}

\begin{tabular}{llll} 
CG & & & \\
Effect Size & $\begin{array}{l}-0.02 \\
\text { Trivial }\end{array}$ & $\begin{array}{l}-0.45 \\
\text { Trivial }\end{array}$ & $\begin{array}{l}-0.66 \\
\text { Small }\end{array}$ \\
SS & & & \\
Effect Size & 0.62 & 0.26 & 0.42 \\
& Small & Trivial & Trivial \\
PNF & & & \\
Effect Size & 1.00 & 0.94 & 0.40 \\
& Small & Small & Trivial \\
\hline
\end{tabular}

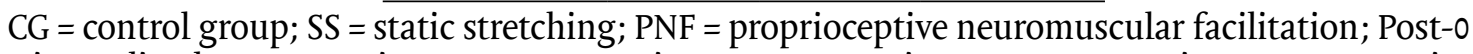
$=$ immediately post exercise; Post- $10=10$-minutes post exercise; Post- $20=20$-minutes post exercise.

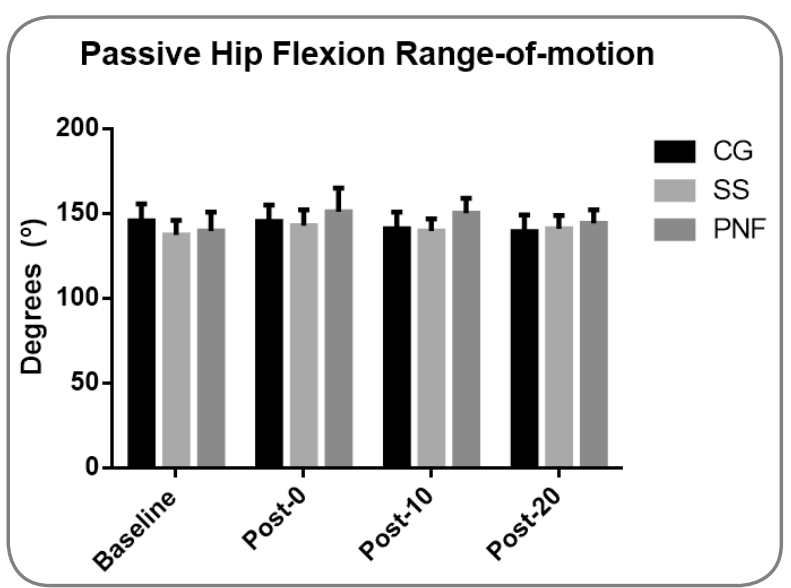

Figure 4 - Response between conditions at different times. 


\section{Discussion}

The purpose of the present study was to compare two methods of stretching on time course passive hip flexion range-of-motion in children classical dancer. There were no statistical differences for CG $(F=0.716 ; p=0.552)$, SS ( $F$ $=0.536 ; \mathrm{p}=0.662)$ and PNF $(\mathrm{F}=1.713 ; \mathrm{p}=0.191)$. Results regarding ES confirm these results, indicating that the highest magnitude presented trivial classification. The results found in the present study agree with the previous literature [35], which found an increase in the flexibility of dancers immediately after stretching techniques (SS and PNF). Rubini et al. [35] investigated the effects of SS and PNF on hip adductors flexibility in female ballet dancers. The authors equalized the stretching volume and indicate increase in SS ( $p<0.001$; ES $=0.39$ ) and PNF ( $p<0.001 ; E S=0.24)$ without difference between stretching techniques. Additionally, Melo et al. [36] found that increases in posterior thigh flexibility in $(p=0.05)$ PNF group $\left(8.78^{\circ}\right)$ when compared to the SS group $\left(6.99^{\circ}\right)$. Wanderley et al. [37] conducted a systematic review that reported low quality of evidence on the efficacy of PNF in comparison with other stretching methods, not allowing declaring to be a superior method.

There is still controversy regarding the technique, the duration, and these variables may have influenced the frequency of stretching when proposing flexibility gain and the results of the present studies. Regarding the stretching volume, Rubini et al. [35] applied an intervention of four sets of 30 seconds with an interval of 30 seconds between sets, while in the present study, we performed 60 seconds of stretching. Tirlonil et al. [38] compared four SS volumes (15-, 60-, 90-, and 120-seconds) on the posterior thigh for popliteal angle PROM. The results found were like the present study (although not statistically), which indicated significant increases in 60-seconds in comparison to the control. In contrast, the authors observed a better dose-response for higher volumes (120$>90$ - > 60- > 15-seconds), which corroborates with Decoster et al. [39], Medeiros and Martini [40], and Wanderley et al. [37]. The results found by Tirlonil et al. [38] were in different populations from our study. This fact makes us believe in interventions with higher volumes for children classical dancer. Dantas [1] indicates that female children are more flexible when compared to males or when compared to adults.

A piece of studies indicates that the flexibility gains depends on the sessions sets number performed [41,42]. For example, Gama et al. [41] analyzed the different number of PNF sets in three stretching groups that received the intervention five days a week for two consecutive weeks. Alternated concerning frequency with one, three, and six manoeuvres per session with the hold-relax technique on posterior thigh flexibility. The results indicated that the flexibility gains in all the experimental protocols when compared to the control group, but there was no significant difference between the experimental protocols. However, the multiple sets (three and six sets) were better for PROM results in comparison to the single sets group, indicating dose-dependence between flexibility and sets number. Gama et al. [42] confirm and indicate a session-dependency for flexibility. The authors tested two different intervals between sessions, 24-hours (total of five sessions per week), and 48-hours (total of three weeks per session). They did not observe statistical differences between the intervals after 10 PNF sessions for the posterior thigh. However, the results indicated a tendency for higher volumes to be more efficient for flexibility gains, 
since the group that performed the stretching five sessions per week indicated gains with fewer sessions. In contrast, Bandy et al. [43] evaluated 93 participants at the optimal stretching frequency of the posterior thigh musculature and found no significant difference between one and three stretching sessions per day.

At our best acknowledge, this is the first study that evaluated the children dancers PROM, as well as the time course effect of flexibility gains. However, Škarabot et al. [30] compared the time course effect of SS and foam rolling, both in isolate performance and the combination of them. The authors found increases in dorsiflexion PROM for all experimental protocols, which remained for up to 20-minutes. Similarly, Monteiro et al. [44] compared the time course effect of foam rolling and rolling massage on hip flexion and extension PROM and found increases in hip PROM for up to 20-minutes. Although different techniques, both studies agree with the findings of the present study, which observed the tendency of the hip PROM for up to 20-minutes. Differently from both studies, the present study compared the effectiveness of two methods and observed that the contract-relax technique (PNF) seems to be more efficient for hip flexion PROM. The time course effect is important for both rehabilitation and ballet specificity, as it is necessary to understand the duration of the results found after stretching techniques.

Over time, to polish the different stretching exercises and sports activities, studies test different warm-up techniques to increase muscle temperature, energy metabolism, viscoelasticity of the soft tissue, rate pressure product, and the transmission speed of the nerve impulse, thus improving the proprioceptors sensitivity, the recruitment of motor units, coordination and the ability to withstand load. The literature is unclear about stretching exercise performance during the warm-up session, but still commonly suggest. Stretching techniques seem to modify the viscosity of the musculotendinous system, redistribute blood flow, and improve the diffusion of available oxygen to muscles $[45,46]$. This fact becomes important in the specificity of ballet practice and should be stimulated as a PROM enhancer.

There are some limitations/delimitations to bear in mind when interpreting the findings in this study. Firstly, the assessed age group seems to have influenced the results chosen, given the fact that children tend to be more flexible than the other age group [1]. Secondly, sports practice seems to have a direct influence on the evaluated variable. It should be taken into account since ballet, and jazz dancers tend to be more flexible due to the functionality of their practice. Finally, single sets with 60 -seconds stretching may be inefficient to promote a satisfactory dose-response in the studied population.

\section{Conclusion}

The results found in the present study indicate that different stretching methods can promote increases in HF and PROM without differences between methods. Besides, the results indicate a decrease in HF and PROM post-10-minutes; this fact makes it possible to apply the stretching techniques immediately before the test or a show, to optimize the range of the ballet movements. Finally, the authors encourage the development of new studies with dancers and flexibility to indicate a better dose-response between stretching methods and volumes. 


\section{Acknowledgments}

The authors thank all the volunteers for their participation.

\section{References}

1. Dantas EHM. Flexibilidade: Alongamento e flexionamento. 4thed. Rio de Janeiro: Shape; 1999.

2. Critchfield B. Stretching for dancers. International Association for Dance Medicine and Science 2011;1-7.

3. Santos D, Mendes L, Alves M, Bonela A, Paz G, Silva J et al. Comparison of different flexibility training methods and specific warm-up on repetition maximum volume in lower limb exercises with female jazz dancers. Journal of Human Sport and Exercise 2018;13(1):19-28. https://doi. org/10.14198/jhse.2018.131.03.

4. Bradley PS, Olsen PD, Portas MD. The effect of static, ballistic, and proprioceptive neuromuscular facilitation stretching on vertical jump performance. J Strength Cond Res 2007;21(1):22336. https://doi.org/10.1519/00124278-200702000-00040

5. ACSM. American College of Sports Medicine. The recommended quantity and quality of exercise for developing and maintaining cardiorespiratory and muscular fitness, and flexibility in healthy adults. Position stand. Med Sci Sports Exerc 1998;30(6):975-91. https://doi. org/10.1097/00005768-199806000-00032

6. ACSM. American College of Sports Medicine. ACSM's guidelines for exercise testing and prescription. 6th ed. Lippincott: Williams \& Wilkins; 2000.

7. ACSM. American College of Sports Medicine. Quantity and quality of exercise for developing and maintaining cardiorespiratory, musculoskeletal, and neuromotor fitness in apparently healthy adults: guidance for prescribing exercise. Med Sci Sports Exerc 2011;43(7):1334-59. https://doi.org/10.1249/MSS.0b013e318213fefb.

8. Leite TB, Costa PB, Leite RD, Novaes JS, Fleck SJ, Simão R. Effects of different number of sets of resistance training on flexibility. Int J Exerc Sci 2017;10(3):354-64. 10.14198/jhse.2018.131.03

9. Behm DG, Chaouachi A. A review of the acute effects of static and dynamic stretching on performance. Eur J Appl Physiol 2011;111:2633-51. https://doi.org/10.1007/s00421-011-1879-2

10. Behm DG, Blazevich AJ, Kay AD, McHugh M. Acute effects of muscle stretching on physical performance, range of motion, and injury incidence in healthy active individuals: a systematic review. Appl Physiol Nutr Metab 2016;41:1-11. https://doi.org/10.1139/apnm-2015-0235

11. Chaouachi A, Padulo J, Kasmi S, Othmen AB Chatra M, Behm DG. Unilateral static and dynamic hamstrings stretching increases contralateral hip flexion range of motion. Clin Physiol Funct Imaging 2017;37:23-29. https://doi.org/10.1111/cpf.12263

12. Funk DC, Swank AM, Mikla BM, Fagan TA, Farr Bk. Impact of prior exercise on hamstring flexibility: a comparison of proprioceptive neuromuscular facilitation and static stretching. J Strength Cond Res 2003;17:489-92. https://doi.org/10.1519/1533-4287(2003)017<0489:iopeoh>2.0.co;2

13. Kay AD, Husbands-Beasley J, Blazevich AJ. Effects of contra-relax, static stretching, and isometric contraction on muscle-tendon mechanics. Med Sci Sports Exerc 2015;47:2181-90. https:// doi.org/10.1249/MSS.0000000000000632

14. Nelson AG, Guillory IK, Cornwell A, Kokkonen J. Inhibition of maximal voluntary isokinetic torque production following stretching is velocity specific. J Strength Cod Res 2001;15:241-6.

15. Martins A, Paz A, Vigário P, Costa e Silva G, Maia M, Miranda H. Static stretching volume is associated with maximal repetitions performance. JEPOnline 2014;17:24-33.

16. Paz GA, Maia MF, Lima VP, Oliveira CG, Bezerra E, Simão R, Miranda H. Maximal exercise performance and electromyography responses after antagonist neuromuscular proprioceptive facilitation: A pilot study. JEP Online 2012;15:60-67.

17. Gomes TM, Simão R, Marques MC, Costa PB, Silva Novaes J. Acute effects of two different stretching methods on local muscular endurance performance. J Strength Cond Res 2011;25:74552. https://doi.org/10.1519/JSC.0b013e3181cc236a.

18. Behm DG, Button DC, Butt JC. Factors affecting force loss with prolonged stretching. Can J 
Appl Physiol 2001;26:261-72.

19. Fowles JR, Sale DG, MacDougall JD. Reduced strength after passive stretch of the human plantar flexors. J Appl Physiol 2000;89:1179-88. https://doi.org/10.1152/jappl.2000.89.3.1179

20. Ogura Y, Miyahara Y, Naito H, Katamoto S, Aoki J. Duration of static stretching influences muscle force production in hamstring muscles. J Strength Cond Res 2007;21:788-92. https://doi. org/10.1519/R-18785.1

21. Power K, Behm D, Cahill F, Carroll M, Young W. An acute bout of static stretching: effects on force and jump performance. Med Sci Sports Exerc 2004;36:1389-96. https://doi.org/10.1249/01. mss.0000135775.51937.53

22. Costa e Silva G, Di Masi F, Paixão A, Bentes CM, Sá M, Miranda H, Simão R, Novaes J. Effects of proprioceptive neuromuscular facilitation stretching and static stretching on cardiovascular responses. JEPOnline 2013;16:117-125.

23. Best TM. Muscle-tendon injuries in young athletes. Clin Sports Med 1995;14:669-86.

24. Herbert R, Gabriel M. Effects of stretching before and after exercise on muscle soreness and risk of injury: Systematic review. Br Med J 2002;325:1-5. https://doi.org/10.1136/bmj.325.7362.468 25. Shellock FG, Prentice WE. Warming-up and stretching for improved physical performance and prevention of sports-related injuries. Sports Med 1995;2:267-78. https://doi. org/10.2165/00007256-198502040-00004

26. Jesus CK, Dantas MF. Proposals choreographic jazz dance in the city Porto Alegre. Arq Mov 2012;8(2):31-43.

27. Faul F, Erdfelder E, Lang A-G, Buchner A. G*Power 3: A flexible statistical power analysis program for the social and biomedical sciences. Behav Res Methods 2007;39:175-91. https://doi. org/10.3758/bfo3193146

28. Beck TW. The importance of a priori sample size estimation in strength and conditioning research. J Strength Cond Res 2013;27:2323-37. https://doi.org/10.1519/JSC.ob013e318278eea0

29. Shepard RJ. PARQ, Canadian Home Fitness Test and exercise screening alternatives. Sports Med 1988;5:185-195.

30. Škarabot J, Beardsley C, Stirn I. Comparing the effects of self-myofascial release with static stretching on ankle range-of-motion in adolescent athletes. Int J Sports Phys Ther 2015;10(2):20312.

31. Sharman MJ, Cresswell AG, Rjek S. Proprioceptive neuromuscular facilitation stretching: mechanisms and clinical applications. Sports Med 2006;36:929-39. https://doi. org/10.2165/00007256-200636110-00002

32. Norkin CC, White DJ. Measurement of joint motion: A guide to goniometry. London: FA Davis; 2009.

33. Moreside J, McGill S. Quantifying normal 3D hip ROM in healthy young adult males with clinical and laboratory tools: hip mobility restrictions appear to be plane-specific. Clin Biomech 2011;26:824-9. https://doi.org/10.1016/j.clinbiomech.2011.03.015.

34. Rhea M. Determining the magnitude of treatment effects in strength training research through the use of the effect size. J Strength Cond Res 2004;18:918-20. https://doi.org/10.1519/14403.1 35. Rubini EC, Souza AC, Melo ML, Bacurau RF, Cabral LF, Farinatti PT. Immediate effect of static and proprioceptive neuromuscular facilitation stretching on hip adductor flexibility in female ballet dancers. J Dance Med Sci 2011;15(4):177-81.

36. Melo RS, Pereira RT, Cunha, IM. Comparação do efeito agudo da deformação muscular nas técnicas de alongamento estático e por facilitação neuromuscular proprioceptiva. Revista Brasileira de Prescrição e Fisiologia do Exercício 2013;7(37):13-20.

37. Wanderley D, Lemos A, Moretti E, Barros MMMB, Velença MM, Oliveira DA. Efficacy of proprioceptive neuromuscular facilitation compared to other stretching modalities in range of motion gain in Young healthy adults: a systematic review. Physiother Theory Pract 2018;23:1-21. https://doi.org/10.1080/09593985.2018.1440677.

38. Tirlonil AT, Belchior ACG, Carvalho PTC, Reis FA. Efeito de diferentes tempos de alongamento na flexibilidade da musculatura posterior da coxa. Fisioter Pesqui 2008;15(1):47-52. https:// doi.org/10.1590/S1809-29502008000100008

39. Decoster LC, Cleland J, Altieri C, Russell P. The effects of hamstring stretching on range of motion: a systematic literature review. J Orthop Sports Phys Ther 2005;35(6):377-87. https//doi. 
org/10.2519/jospt.2005.35.6.377

40. Medeiros DM, Martini TF. Chronic Effect of different types of stretching on ankle dorsiflexion range of motion: systematic review and meta-analysis. Foot (Edinb) 2017;34:28-35. https:// doi.org/10.1016/j.foot.2017.09.006

41. Gama ZAS, Medeiros AS, Dantas AVR, Souza TO. Influência da frequência de alongamento utilizando facilitação neuromuscular proprioceptiva na flexibilidade dos músculos isquiotibiais. Revista Brasileira de Medicina do Esporte 2007;13(1):33-8. https://doi.org/10.1590/S151786922007000100008

42. Gama ZAS, Dantas AVR, Souza TO. Influência do intervalo de tempo entre as sessões de alongamento no ganho de flexibilidade dos isquiotibiais. Revista Brasileira de Medicina do Esporte 2009;15(2):110-14. https://doi.org/10.1590/S1517-86922009000200005

43. Bandy WD, Irion JM, Briggler M. The effect of time and frequency of static stretching on flexibility of the hamstring muscle. Phys Ther 1997;77(10):1090-7. https://doi.org/10.1093/ $\mathrm{ptj} / 77.10 .1090$

44. Monteiro ER, Vigotsky AD, Novaes JDS, Škarabot J. Acute effects of different anterior thigh self-massage on hip range-of-motion in trained men. Int J Sports Phys Ther 2018;13(1):104-13.

45. Bishop D. Warm up I: potential mechanisms and the effects of passive warm-up on exercise performance. Sports Med 2003;33(6):439-54. https://doi.org/10.2165/00007256-200333060-00005 46. Young WB, Behm DG. Should static stretching be used during a warm-up for strength and activities? J Strength Cond Res 2002;24(6):33-7. https://doi.org/10.1519/00126548-20021200000006 